\title{
Institutional Markets for Family Agriculture: Analysis of the Food Acquisition Program (PAA) and the National School Feeding Program (PNAE) within a Territory in the Brazilian Amazon ${ }^{1}$
}

\author{
G. X. Paula Filho*, M. F. Calvi**, R. R. A. Castro***. \\ * Field Education College. Agroecology. Amapá Federal University, Amapá State, Brazil. \\ ** Forest Engineering College. Family Agriculture. Pará Federal University, Pará State, Brazil. \\ *** Transamazonian Territorial Development Extension Center. \\ Pará Federal University, Pará State, Brazil.
}

\begin{abstract}
Hunger and malnourishment control and school meal programs became commercialization channels for family production and have been implemented mainly by way of the Food Acquisition Program (PAA) and the National School Feeding Program (PNAE). The objective of this work is to evaluate access to the $P A A$ and the PNAE by family farmers within the Transamazonian Territory, which is a central region in the Brazilian Amazon. To obtain the information, semistructured questionnaires were applied to the implementing organizations and the farmers who benefited from the aforementioned programs in the year of 2014. The data obtained was analyzed by way of descriptive and inferential statistics. A reduced access to these programs was observed, which is associated to a strong bureaucratic process, a delay in the approval of projects (PAA), a delay in payment by the city halls, difficulty in issuing invoices and political instability within the cities (PNAE). The conclusion was that the effectuation of these programs is directly related to the socioeconomic and productive dynamics of the cities, and depends on the participation of farmer organizations, buying agents and especially on the political will of the managers.
\end{abstract}

Keywords: Family agriculture, Nutritional and Food Security, Transamazonian Territory, PNAE, PAA.

\section{INTRODUCTION}

By analyzing the efforts undertaken towards the inclusion of family agricultural production in consumer markets within the last decade, one may find experiences and initiatives by producers and public $\theta$ managers that seek to verticalise production and promote economic sustainabilty of the family units in all regions of Brazil (Melão, 2012; Valnier and Ricci, 2013; Mota et al., 2014), by way of strategies that make this production available for school meal programs (Turpin, 2009) and/or social programs that help people in situations of food and nutritional insecurity (Maluf, 2006; Chmielewska and Souza, 2010).

In many cases, the search for inclusion of family production in institutional markets is confused with the organizational forms (Torres et al., 2011), or arise from initiatives aiming at the possibility of farmers uniting themselves in order to strengthen the production system, and, posteriorly, the strategies of collective and joint commercialization (Silva and Egito, 2005).

On this last decade, Brazilian family farmers have been experimenting with a new institutionalized stage of individual and collective purchase, mainly by way of the Food Acquisition Program (PAA) and the National School Feeding Program (PNAE). The emergence of these programs is inserted within a larger strategy of the Brazilian government, by way of several ministries, especially the Social Development and Hunger Prevention Ministry (MDS) and the Agricultural Development Ministry (MDA), to eradicate misery and extreme poverty in the country (Maluf and Zimmermann, 2005), which also resulted in opportunities to create intake channels for familial agricultural production (Simão et al., 2014).

\footnotetext{
1 Work elaborated from the actions of Pará University's Territorial Development Extension Center (NEDET/UFPA) in the Transamazonian Territory. It counted with the financial assistance of the Territorial Development Office of the Agricultural Development Ministry (SDT/MDA) and the National Scientific and Technologic Development Council (CNPq).
} 


\section{G. X. Paula Filho et al.}

The PAA was instituted by Law $n^{\circ} 10.696$, dated July 2nd 2003, and has two basic goals: to promote access to food and to encourage family farming, promoting the acquisition of food by family farmers, directly or by way of their organizations, with an exemption from bidding and with the intent of forming governmental stocks for donations to people in a situation of food and nutritional insecurity (Brasil, 2003). The objectives of the program are the remuneration of production, occupation of rural space, income distribution, hunger prevention, appreciation of regional food culture and contribution towards environmental preservation, supporting agricultural biodiversity and encouraging sustainable food production systems (National Supply Company, 2015). Preliminary data from the MDS points out that in 2014 alone, the PAA bought food from 107.120 farmers throughout Brazil, with a total investment of US\$ 135.130.929,50, equivalent to 291.660.710,27 kilos of obtained food (Information Management and Assessment Office, 2015).

The PNAE is Brazil's largest and oldest national program in the area of feeding and nutrition, both in allocated resources and in the number of individuals served, and is considered the largest school meal program in the world (Peixinho et al., 2011). The program began in the 1940's , but it was in 2009, by way of Law $\mathrm{n}^{\circ} 11.947$, that the extension of this program to the entire basic education public network took place, by guaranteeing that at least $30 \%$ of transfers from the National Fund for Education Development (FNDE) invested in the acquisition of family farming products (Brasil, 2009). The transfer of resources is made directly to the states and cities, based on the school census, and the program is monitored and supervised by the School Meal Councils (CAE), by the FNDE, by the Union Audits Office (TCU), by the Union General Controllership (CGU) and by the Federal Prosecutor's Office(National Fund for Education Development, 2015). In the year of 2014 alone, this program invested US\$ 922.5 million in the acquisition of food from family farming and benefited 42.2 million students across Brazil (National Fund for Education Development, 2015).

The participation of family farming products in school meals is important, due to the contribution of this segment towards feeding and nutritional security, and towards the sovereignty of this group of producers (Triches and Schneider, 2010). Ozelame et al. (2007) and Burity et al. (2010) emphasize that food sovereignty of the family farmers keeps them less dependent on industrialized food and less vulnerable to market oscillations, unlike producers of commodities who are connected to the raw materials market, and as such, become more dependent and vulnerable to the oscillations that occur in that arena.

As such, a series of experiences came about by farmers who started accessing these markets throughout the country (Lopes and Almeida, 2012; Hilgert et al. 2014; Mota et al., 2014). These purchase modalities are instituted within the strategy of the Crop of Family Farming Plan, and became effective in the Transamazonian Territory, which is a central region of the Brazilian Amazon, where dozens of farmers, by way of individual and collective purchase, have accessed these programs and obtained promising results in their production systems. However, although these experiences are successful, there are still a number of technical and productive infrastructure-related limitations, which make the effectiveness of these programs in this region difficult. Experiences with institutional purchases have been taking place for at least half a decade, and during those years, the experiences of the local farmers resulted in a new relationship between the buyer agents (National Supply Company - CONAB and city halls) and family farmers.

\subsection{Objectives of the Study}

The planning of this study is contemplated in the actions of the Monitoring and assessment of public policies for territory management in the Pará Amazon project, undertaken by way of the partnership between the MDA and the National Scientific and Technologic Development Council (CNPq), and carried out by the Pará Federal University (UFPA), which evaluates the productive inclusion policies for family farming, in order to elucidate the main impacts of these policies on socioeconomic and productive aspects and at the local and regional dimensions for the family farming segment, as well as the main limitations of the effectuation of the policies by all the actors involved (public authority, farmer organizations and the farmers themselves). As such, the present work has the goal of 
evaluating the access of family farmers from the Transamazonian Territory, in the Brazilian Amazon, to two of the main productive inclusion programs for family farming: the PAA and the PNAE, observing the main potentials and limitations for the implementation of these programs.

\subsection{Theoretical Foundation}

According to Graziano da Silva et al. (2010), the debate regarding food and nutritional security, the possibilities of inclusion of local family farming production in the school menu and in poverty prevention programs has been ongoing in Brazil since the first half of last century. However, these initiatives received more attention from the government and civil society after the re democratization of the country, especially with the promulgation of the Federal Constitution in 1988, which established that public school feeding must be maintained until elementary school.

With regards to hunger and malnutrition prevention, for many years this was associated with low agricultural productivity. However, some studies have showed that one of the main factors responsible for hunger is not the lack of food, but rather of access to it. (Rocha, 2009; National Food and Nutritional Security Council, 2010; Applied Economic Research Institute, 2010). This finding was essential for the implementation of public policies for the productive inclusion of family farming, so much so that the Brazilian experience with extreme poverty and misery prevention by way of family farming products is held as an example for other countries, who began seeking similar productive inclusion and hunger prevention models (Chmielewska and Souza, 2010).

It is important to note that, although the conservative sectors of society demonstrate resistance to programs of acquisition of products for school meals, as well as of hunger and malnutrition prevention, programs of this type exist in many countries in the world. As an example, one may cite the Supplemental Nutrition Assistance Program, previously known as Food Stamp Program, considered the biggest food security program in the United States (Coleman-Jensen et al., 2011). This program, as well as the PAA and the PNAE, also has conditions and criteria for access, and until the end of the first decade of the 21st century, already served 7.3 million households and 17.2 million people per month across the country (Graziano da Silva et al., 2010). Still in the United States, according to Izumi et al. (2010), there is a broad school meal program, which works by way of farm networks that produce for rural schools, where, in 2005, there were more than 1900 schools being served, receiving technical assistance and financial support for food crop growth.

Riches (2002) highlights the examples of Canada and England, citing them as countries with food banks, based on a decentralized federal system of purchase of food products from local farmers, whose food is donated to people under the risk of food or to social non-profit organizations that supply complementary meals. In these countries, the food is acquired with public funds, with the objective of preventing poverty and food and nutritional insecurity. These food banks have become established as potential sources of inclusion of local agricultural production. Several Canadian food banks have stood out, such as Toronto's Daily Bread Food Bank, Greater Vancouver Food Bank and System of Moissons, the latter belonging to the province of Quebec.

In Asia, the most promising experience with the acquisition of family farming products for school meals in the last years is taking place in India, by way of the National Program for Nutritional Support to Primary School, created in 1995, where the State finances the school meals in public schools; the food is acquired from the students' parents' properties and a minimal attendance of at least $80 \%$ is demanded of the children in the schools (Afridi, 2010).

Belik and Souza (2009) state that Latin America, since the beginning of the 21st century, has become a den of experiences with policies of food acquisition for people in a situation of poverty and social vulnerability and for school feeding, functioning by way of actions integrated between several ministries with emphasis on food and nutritional security, resulting in possibilities of inclusion for family farming products. Analyzing the origin of these programs, Levine (2008) states that school feeding programs in particular became widespread within Latin America in the 1950s, from fund 


\section{G. X. Paula Filho et al.}

transfers from international humanitarian help, such as the American Public Law 480 ${ }^{2}$, program, in which the food donation had the goal of reducing the surplus of agricultural production in the United States.

In Ecuador, Barona (2010) cites the experience of the Programa de Alimentácion Escolar which has, since, 2003, been financed exclusively with funds from the National Government, in cooperation with the United Nations Program for Development (PNUD) and the municipal governments, who purchase local agricultural production and supply it to primary schools; and the Programa Alimentáte Ecuador, which has, since 2008, functioned entirely with public funds. This program hires products from family agriculture by way of a Public Purchase Gate and provides food assistance for children in a state of social vulnerability of up to five years of age, the elderly (from 65 years of age) and people considered as being below the poverty line.

In Nicaragua, there is the Programa Integral de Nutrición Escolar, which coordinates many other actions of government offices and ministries and aims at truancy prevention, offering school meals to primary school students and the acquisition of food from local producers (Contreras, 2009).

Chile possesses a school meal program with a universal proposal. However, it is focused in the sense that only students of lower income obtain access to food. This program is administered in a centralized way by the National Board of School Aid and Scholarships (JUNAEB), tasked with making school feeding purchases, acquired from local producers and students' parents, and defining the beneficiaries of the program (Belik and Souza, 2009).

Brazil is regarded as a successful case of programs based on family farming food acquisition for social initiatives and schol meals (Fabri et al., 2015; Mendonça and Rocha, 2015). Like the other countries in Latin America, in Brazil, the food acquisition programs, especially the PNAE, at its inception, acquired its supplies based on the availability of donations of food resources by other nations, such as the United States, and programs such as the Public Law (PL) 480. Later, during the following decades, the PNAE and the $P L$ further structured themselves, receiving different directives regarding the acquisition and destination of the food, in such a way that, currently, Brazil purchases the family farming food and directs it towards social and school meal programs through the PAA and PNAE, encouraging individual entrepreneurship and collective organization forms.

\section{Methodology}

There are difficulties in establishing specific methodologies to assess access to public policies in Brazil due to the diversity of the policies and the fields in which they apply. The analysis depends on the object being evaluated, the field it encompasses, and especially the variables of interest, so that arrangements more appropriate to the intended investigation may be established. However, these arrangements must contemplate the interest of the study and be validated from a methodological point of view.

With regards to acess to the PAA and PNAE, recent literature on the subject contains mostly qualitative analyses (Turpin, 2009; Triches and Schneider, 2010; Torres et al., 2011; Lopes and Almeida, 2012; Melão, 2012; Dias et al., 2013; Valnier and Ricci, 2013; Hilgert et al. 2014; Mota et al., 2014; Santos et al., 2014; Simão et al., 2014). Analyses with quantitative indicators regarding these programs are not available, and even if they were, caution would be necessary when adopting these studies' methodologies as a standard, seeing as both are nationwide programs, whose effectiveness depends mainly on the socioeconomic performance of the cities where they operate, which are known to be widely heterogeneous, as well as the abilities and interest of the involved public managers.

The field procedures showed different results among the farmers in the cities analysed within the same territory with regards to access to the PAA and PNAE, in which some of them obtained a greater percentage of access. As such, how to materialize the information, or adjust it to a model that explains these differences?

\footnotetext{
${ }^{2}$ The Public Law 480 was approved in 1954 in the United States and aimed at purchasing food surpluses from producers, for donation to poor countries. Internally, it represented a subsidy to farmers and a way of stabilizing market prices (Belik and Souza, 2009).
} 


\subsection{Study Area}

The research was undertaken during the year of 2014. The study area encompassed the cities of Pacajá, Anapu, Porto de Moz, Senador José Porfírio, Vitória do Xingu, Altamira, Brasil Novo, Medicilândia, Uruará and Placas, which constitute the Transamazonian Territory, in the state of Pará, a central region of the Brazilian Amazon (figure 1).

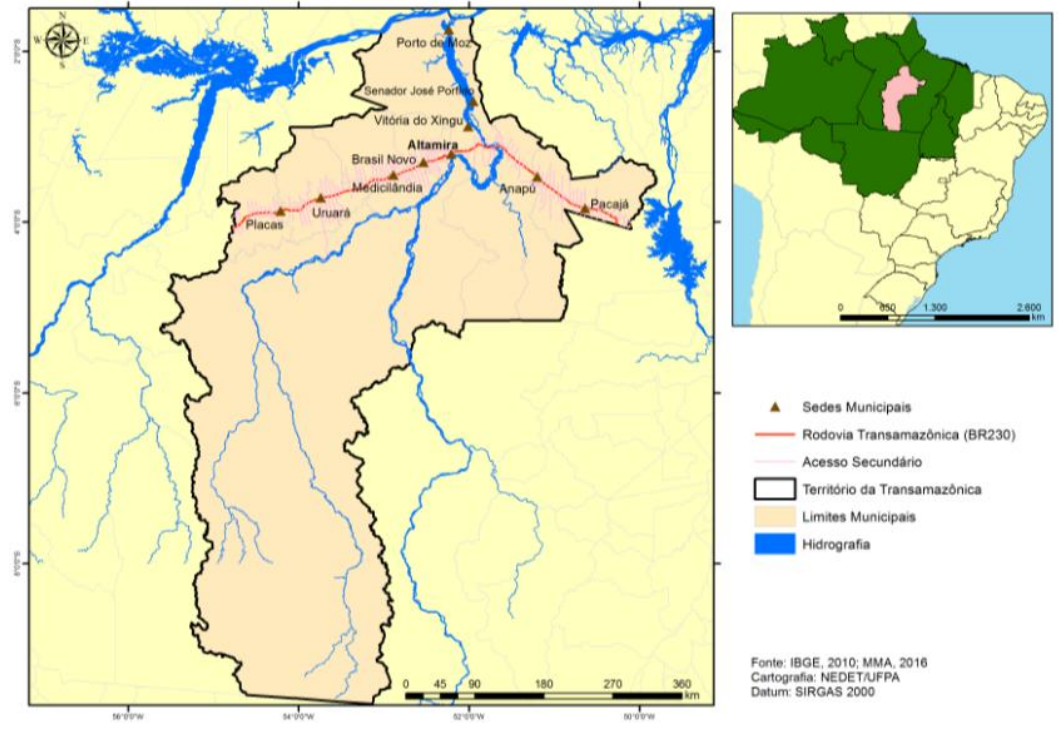

Figure1. Study area. Transamazonian Territory, Amazon, Brazil.

\subsection{Field Procedures}

The first stage of the work arose from a demand from the Transamazonian Territorial Development Extension Center (NEDET/UFPA), which, through structured questionnaires, collected information regarding the performances of these programs in the cities of the Territory. The questionnaires were applied to sixteen (16) farmers who were beneficiaries of the PAA and PNAE, who commercialized for the programs, in the individual or collective modalities, by way of associations or cooperative enterprises. This number of farmers represented 100\% of all the beneficiaries of this program in 2014 in that Territory.

Questionnaires were also applied to seven (07) farmer organizations, among associations and cooperative enterprises who commercialized family farming products in the collective modality. These organizations represented 233 farmers associated with them, who are directly covered by the programs evaluated in this study.

Aside from them, the research list also included governmental agents such as the municipal school feeding departments, who are responsible for the direct purchase of the products. With these agents, open interviews were conducted, in order to obtain information regarding the appointment of beneficiaries of the programs, and also to confirm data obtained from farmers and supplier entities and from secondary sources.

\subsection{Analytical Procedures}

The analysis of access to the programs was carried out in a particularized and individual form between the farmers of the cities that compose the Territory, verifying the performance level of a city in relation to another by way of descriptive and inferential statistics. In this sense, a hypothesis was elaborated in which cities with a higher degree of access to information, local development or schooling of its farmers may be more susceptible to the execution of these programs. At the same time, the social environment and the socioeconomic dynamic associated with the production possibilities of the cities are factors that may contribute towards greater access to the programs.

\section{RESUltS AND DisCUSSION}

The PAA was accessed only in a collective form, through the farmer organizations, while the PNAE was accessed in a collective form, through organizations, an in an individual form, by the farmers. The analysis of the results is divided in the following three categories: 


\section{G. X. Paula Filho et al.}

\subsection{Access to the PAA}

In this modality, a total of 96 farmers were benefited, 43 of which were farmers of the Carlos Pena Filho Agrovillage Rural and Urban Producers Association (APRUCAPEFI) in the Brasil Novo city; 31 were connected to the Solidary Economic and Ecologic Amazon Fruit Association (ASSEEFFA) in Anapu, and 22 farmers were from the Dom Oscar Romero Women Association (AMDOR) in Uruará.

AMDOR and ASSEEFA commercialized production in their cities. However, APRUCAPEFI commercialized not only within its own city, Brasil Novo, but also for philanthropic organizations in the city of Altamira (Table 01).

Table1. Data related to access of the PAA by family farmer organizations in the Transamazonian Territory, Amazon, Brazil.

\begin{tabular}{|l|l|l|l|}
\hline Municipality & Organization & $\begin{array}{l}\text { Number of farmers } \\
\text { benefited }\end{array}$ & \% of farmers benefited \\
\hline Uruará & AMDOR & 22 & 23 \\
\hline Brasil Novo & APRUCAPEFI & 43 & 45 \\
\hline Anapu & ASSEEFA & 31 & 32 \\
\hline Total & & $\mathbf{9 6}$ & $\mathbf{1 0 0}$ \\
\hline
\end{tabular}

Academic literature regarding this program shows that access to it has occurred mainly through farmer organizations (Valnier and Ricci, 2013; Hilgert et al. 2014), which corroborates the results found in this study, observed in table 01 , where one may note that among the farmers covered with PAA resources, $45 \%$ are situated in the city of Brasil Novo, even though part of the production was also commercialized in the city of Altamira.

Likewise, the difficulties and challenges faced by the farmer organizations in the Transamazonian Territory corroborate the results found by Dias et al. (2013) in a work carried out with family farmers in a Brazilian Northeast Territory, in which the regularization of documents such as the Declaration of Aptitude to the PRONAF (DAP) and the National Registry of Legal Entities (CNPJ), as well as the difficulties in the development of projects have been the greatest hurdles preventing access to the PAA by the family farmers connected to the collective organizations.

According to the Brazilian Agropecuary Census (Brazilian Institute of Geography and Statistics, 2006), in the Transamazonian Territory there are 20,883 agropecuary establishments; the results found in this study show that only 96 of these, or $0.5 \%$, were covered by the PAA in the entire Territory. As such, access to this program is considered to be low. Farmers and technicians who were interviewed associate this to the high level of bureaucracy in the process of accountability of awarded funds and CONAB's delay in approving the projects, resulting in farmer organizations giving priority to commercialization with PNAE, due to, according to them, a process involving less bureaucracy. These same problems were observed in similar works carried out by Lopes and Almeida (2012) and Silva et al. (2012), in the cities of Castilho and Andradina (São Paulo State) and in the city of Viçosa (Minas Gerais State), respectively; both carried out with the beneficiaries of these programs.

Furthermore, the PAA has made possible the creation of sociability spaces valuing products that are unmarketable in the conventional market, such as native regional products not produced on a commercial scale, such as the flour from the mesocarp of the babaçu (Orbignya phalerata Mart.), among others, which are, however, commercialized in fairs and markets, which has contributed towards the improvement of the life quality and self-esteem of farmers inserted in this modality of commercialization, as observed by Mota et al. (2014). Analyzing the dynamic of the PAA in the states of the Brazilian Amazon, Valnier and Ricci (2013) point out that the Program is still in the process of improvement and needs greater divulgation and greater adjustment to the regional specificities in order to achieve a greater participation of farmers.

\subsection{Access to the PNAE}

The PNAE was the most accessed productive inclusion program by farmers of the Transamazonian Territory in 2014, from two formats: by way of family farmer associations and cooperative enterprises and in individual manner. 
Institutional Markets for Family Agriculture: Analysis of the Food Acquisition Program (PAA) and the National School Feeding Program (PNAE) Within a Territory in the Brazilian Amazon ${ }^{1}$

\subsubsection{Access to the PNAE through Family Farmer Associations and Cooperative Enterprises}

In this modality, there was participation of seven farmer organizations across the Transamazonian Territory, involving 233 farmers. The organizations and farmers who accessed the PAA also accessed the PNAE.

The cities of Uruará and Pacajá stood out as those with the greatest number of organizations (Forest Seeds Agroextractivist Association (AASFLOR) and AMDOR, in Uruará; and Marketers, Environmental Preservation and Sustainable Developmen Association of Pacajá (AFEPAC) and Transamazonian Organic Cocoa Producers Cooperative (COOPCAO), in Pacajá); in Brasil Novo, Medicilândia and Anapu there was participation from only one organization in each city: the APRUCAPEFI, the Transamazonian Agroindustrial Cooperative (COOPATRANS) and the ASSEEFA, respectively (Table 2).

Table2. Data regarding access to the PNAE by family farmer organizations in the Transamazonian Territory, Amazon, Brazil, in 2014.

\begin{tabular}{|c|c|c|c|c|}
\hline \multirow{2}{*}{ Municipality } & Organization & $\begin{array}{c}\text { Number of } \\
\text { farmers benefited }\end{array}$ & \multirow{2}{*}{$\begin{array}{c}\text { \% of farmers } \\
\text { benefited by } \\
\text { municipality }\end{array}$} & $\begin{array}{c}\text { \% of farmers } \\
\text { benefited by } \\
\text { organizatio }\end{array}$ \\
\hline \multirow{2}{*}{ Uruará } & AASFLOR & 40 & $27 \%$ & $17 \%$ \\
\cline { 2 - 3 } \cline { 5 - 5 } & AMDOR & 22 & \multirow{2}{*}{$25 \%$} & $10 \%$ \\
\hline \multirow{2}{*}{ Pacajá } & AFEPAC & 32 & $18 \%$ & $11 \%$ \\
\hline Brasil Novo & COOPCAO & 25 & $17 \%$ & $18 \%$ \\
\hline Medicilândia & COOPATRAPEFI & 43 & $13 \%$ & $17 \%$ \\
\hline Anapu & ASSEEFA & 40 & $\mathbf{1 0 0 \%}$ & $\mathbf{1 0 0 \%}$ \\
\hline Territory & $\mathbf{7}$ organizations & $\mathbf{2 3 3}$ & \\
\hline
\end{tabular}

The city of Uruará obtained a larger percentage of farmers who benefited from the PNAE (27\%), followed by Pacajá (25\%). However, the organization with the greatest participation in this program was the APRUCAPEFI, with $18 \%$ of all farmers in the Transamazonian Territory who accessed the PNAE being associated to that organization, followed by AASFLOR and COOPATRANS, both with $17 \%$.

With regards to the APRUCAPEFI, this is the only organization that commercializes its production outside of its city of origin (Brasil Novo), also allocating its products to the School Meals Department of the city of Altamira. This situation resembles the one observed by Stolarski and Castro (2007), in a study carried out regarding the PNAE during the years of 2003 and 2004, in the state of Paraná. These authors observed that $26.7 \%$ of the commercialized production within the scope of this program was allocated to the city halls of cities other than those where the products were made.

The potential, highlighted by those interviewed, relates to the small scale commercialization opportunities for some products without visibility in the conventional market and the recognition, by teachersand students, of the quality of the offered food. These results corroborate works found in the literature of Belik and Souza (2009) and Lopes and Almeida (2012), who observed that same level of satisfaction by farmers who supplied products for school meals in other regions of Brazil.

The greatest difficulties encountered for the execution of the program, which interfered in access by the farmers, were related to the delay in the payment by some municipalities, a situation also identified in a research carried out by Stolarski and Castro (2007) across Brazil; as well as the difficulty in emitting invoices, considered one of the greatest hurdles encountered for the execution of the PNAE, according to a literature review carried out by Saraiva et al. (2013), regarding the program in all regions of Brazil.

\subsubsection{Access to the PNAE in an Individual Form by Farmers}

In this modality, 16 farmers accessed the PNAE in the year of 2014, in six cities of the Territory. The city of Medicilândia stood out, with five farmers covered, which is equivalent to $31 \%$ of those benefited, followed by the cities of Porto de Moz, Vitória do Xingu and Placas, with four, three and two farmers covered; percentages of 25,19 and $13 \%$ of the total number, respectively. In Senador José Porfírio and Brasil Novo, only one farmer was covered in each city, which is equivalent to $6 \%$ of the total number (table 3). 
Table3. Data Regarding Access to the PNAE, in the Individual Modality, by Family Farmers in the Transamazonian Territory, Amazon, Brazil, in 2014.

\begin{tabular}{|c|c|c|}
\hline Municipality & $\begin{array}{c}\text { Number of farmers benefited } \\
\text { in the municipality }\end{array}$ & $\begin{array}{c}\text { \% of farmers benefited in the } \\
\text { municipality }\end{array}$ \\
\hline Medicilândia & 5 & 31 \\
\hline Porto de Moz & 4 & 25 \\
\hline Vitória do Xingu & 3 & 19 \\
\hline Placas & 2 & 13 \\
\hline Brasil Novo & 1 & 6 \\
\hline Senador José Porfírio & 1 & 6 \\
\hline Total & $\mathbf{1 6}$ & $\mathbf{1 0 0}$ \\
\hline
\end{tabular}

In the modality of individual access to this program, one may notice the aforementioned specificity in the commercialization throughassociations, which are the school meals departments that buy food in other cities. As an example, the city of Vitória do Xingu stands out, where the three farmers who were beneficiaries of the PNAE in the individual modality supplied their production to Altamira. However, that same city (Vitória do Xingu) purchases from the only beneficiary farmer from Brasil Novo. In this case, Vitória do Xingu didn't purchase from local farmers, but rather from a farmer from another city, while Altamira stands out as an important consumer of food from the PNAE, although there were no local producers being benefited by the program.

With regards to the potentials and difficulties in access to this program in its individual modality by family farmers, the same issues arise as those observed in the collective commercialization modality. Regarding the difficulties, it was observed that the city halls prioritizes the insertion of farmers from the same group/political party as that which occupies power during the current mandate, rather than farmers from opposing parties.

\subsection{Technical and Political Implications Observed in the Present Study}

Based on the information gathered in the field, and with a view to assessing these programs, one asks: what does it take for a city to access (or not access) a particular program? How to answer this? By carrying out a brief review of academic papers and official documents that attempted to seek this answer, one notes that access to the rural development public policies by city halls is also associated with the level of local development of these cities. The implementation of these policies depends on a certain level of instruction and information of the local population, as well as the importance given by managers to these (National Supply Company, 2013; Souza-Esquerdo and Bergamasco, 2014).

However, in the region of this study, results were encountered that differ from those pointed out by the literature, such as the city of Altamira, the most developed in the region, with the best socioeconomic indicators. In spite of such conditions, none of the assessed programs were implemented in this city, unlike other cities with relatively low social and economic indicators, such as Pacajá, Placas and Porto de Moz, who had better performances.

It is worth noting that, in each city, there is a socioeconomic and productive specificity and dynamic to be considered, such as the number of agropecuary establishments; the environmental liabilities of the rural properties; the infrastructure of vicinal roads for the transport of production; the presence or absence of rural electrification that may limit some productive activities, such as the production of fruit pulps; the existence of large public or private enterprises that might attract field labour ${ }^{3}$. However, the success or failure in the execution of these family farming productive inclusion programs depends, primordially, on the initiative of public managers and the involvement of civil society organizations, who, in some s cases, as was found in this study, either don't know or demonstrate enormous technical difficulty in operationalizing them.

In the cities of Brasil Novo, Uruará, Medicilândia and Pacajá, who stood out in some commercialization modalities of the analyzed programs, a greater involvement of local organizations, farmer associations and cooperative enterprises in the process of effectuation was observed, both in

\footnotetext{
${ }^{3}$ For example, during the time of the undertaking of this study, two large projects of the Brazil Growth Acceleration Program (PAC) were being implemented, which had a high labor demand: the construction of the Belo Monte Hydroelectric Power Plant and the Paving of Highway BR 230.
} 
Institutional Markets for Family Agriculture: Analysis of the Food Acquisition Program (PAA) and the National School Feeding Program (PNAE) Within a Territory in the Brazilian Amazon ${ }^{1}$

the sense of seeking possibilities to execute them, as well as in the search for information regarding their management.

\section{Conclusions}

A situation of low access by the farmers in these productive inclusion programs in the Transamazonian Territory was observed. The smallest indicator is related to the PAA, which was only accessed by three farmer organizations, due to bureaucratic reasons and a delay by the CONAB in approving the projects. As such, the organizations that access it tend to opt for the PNAE, given the lesser degree of bureaucracy, in either the individual or collective modalities. It is worth noting, as a positive point of the PAA, the construction of a new commercialization channel between the farmers and CONAB.

With regards to the PNAE, only seven organizations and sixteen farmers in the individual modality accessed this program throughout the Territory in 2014. Considering the number of agropecuary establishments that exist in the Transamazonian Territory, one concludes that access by farmers to this program is low. There is a set of limitations to the implementation of the PNAE, such as the difficulty in emitting invoices, associated with the delay in payment by city halls and the favoring of some farmers over others based on their political party choice, which has contributed to other farmers destining their production only to the conventional market. However, there are positive points to be highlighted, which are the offer of a more nutritious and healthy school meal system, and the possibility of commercialization of family farming products that are not commercialized in the conventional market due to their low quantity and seasonality.

This work does not exhaust the debate regarding the assessment of productive inclusion programs for family farming. It may contribute in the evaluation of access to these programs, from the specificities of each city, considering physical and productive s factors and, mainly, the socioeconomic and political dynamic of these cities.

\section{ACKNOWLEDGEMENTS}

The authors thank SDT/MDA and CNPq for the financial support for the undertaking of this research (Project: 4009936/2013-8), the public managers and farmers for their willingness to participate in this study.

\section{BIBLIOGRAPHIC REFERENCES}

Afridi, F. (2010). Child welfare programs and child nutrition: Evidence from a mandated school meal program in India. Journal of Development Economics, 92: 152-165.

Barona, C.C. (2010). Políticas públicas em alimentación y nutrción: eficiencia del gasto em los programas de alimentación social de Ecuador. 2010. 118f. Tesis (Maestría em Ciencias Sociales) - Facultad Latinoamericana de Ciencias Sociales, Quito.

Belik, W.; Souza, L.R. (2009). Algumas reflexões sobre os programas de alimentação escolar na América Latina. Planejamento e políticas públicas, 1 (33):103-122, 2009.

Brasil. Lei $\mathrm{n}^{\circ}$ 10.696, de 02 de julho de 2003. Dispõe sobre a repactuação e o alongamento de dívidas oriundas de operações de crédito rural, e dá outras providências. Diário Oficial da União, seção 1, p.1, 03 jul 2003.

Brasil. Lei $\mathrm{n}^{\circ} 11.947$, de 16 de junho de 2009. Dispõe sobre o atendimento da alimentação escolar e do Programa Dinheiro Direto na Escola aos alunos da educação básica. Diário Oficial da União, seção 1, p.2, 17 jun 2009.

Burity, V.; Franceschini, T.; Valente, F.; Recine, E.; Leão, M.; Carvalho, M. F. (2010). Direito humano à alimentação adequada no contexto da segurança alimentar e nutricional. ABRANDH: Brasília, DF, 204 p.

Chmielewska, D.; Souza, D. (2010). Market alternatives for smallholder farmers in food security initiatives: Lessons from the Brazilian Food Acquisition Programme. Brasilia: International Policy Centre for Inclusive Growth, n.64, 21 p.

Coleman-Jensen, A.; Nord, M.; Andrews, M.; Carlson, S. (2011). Household Food Security in the United States in 2010. Washigton D.C.: USDA, n.125, 29 p. 


\section{G. X. Paula Filho et al.}

Companhia Nacional de Abastecimento. (2015). Agricultura e abastecimento em boa companhia. Brasília: Companhia Nacional de Abastecimento, [2015]. Disponível em: http://www.conab.gov.br/conteudos.php?a=1125. Acesso em 16 abr. 2015.

Companhia Nacional de Abastecimento. (2013). Relatório de Gestão - Exercício 2012. Rio Branco: CONAB. 2013. 63 p.

Conselho Nacional de Segurança Alimentar e Nutricional. (2010). A segurança alimentar $e$ nutricional e direito humano à alimentação adequada no Brasil: indicadores e monitoramento, da Constituição de 1988 aos dias atuais. Brasília: CONSEA. 284 p.

Contreras, F.L.V. (2009). Los processos educativos en Waslala, Raan. Ciencia e interculturalidad, v.5, n.2, p.26-49.

Dias, T.F.; Nunes, E.M.; Torres, F.L.; Torres, A.C.M. (2013). O Programa de Aquisição de Alimentos da Agricultura Familiar (PAA) como estratégia de inserção socioeconômica: o caso do Território da Cidadania Sertão do Apodi (RN). Revista Brasileira de Gestão e Desenvolvimento Rural, 9 (3): 100-129.

Fabri, R.K.; Proença, R.P.C.; Martinelli, S.S.; Cavalli, S.B. (2015). Regional foods in Brazilian school meals. British Food Journal, 117 (6): 1-16.

Fundo Nacional para o Desenvolvimento da Educação. (2015). Programas / PNAE / Apresentação. Brasília: Fundo Nacional de Desenvolvimento da Educação, [2015]. Disponível em: http://www.fnde.gov.br/index.php/programas/alimentacao-escolar/alimentacao-escolarapresentacao. Acesso em 11 abr. 2015.

Graziano da Silva, J.; Del Grossi, M.E.; França, C.G. (Orgs.). (2010). Fome Zero: a experiência brasileira. Brasília: MDA, 2010. 360p.

Hilgert, M.; Refati, D.C.; Zonin, W.J.; Corbari, F.; Gregolin, M.R.P. (2014). PAA e PNAE: agentes para a transição agroecológica no município de Missal/PR. Cadernos de Agroecologia, 9 (1):1-5.

Instituto Brasileiro de Geografia e Estatística. (2015). Censo agropecuário 2006. Rio de Janeiro: Instituto Brasileiro de Geografia e Estatística, [2006]. Disponível em: http://www.cidades.ibge.gov.br/xtras/temas.php?lang=\&codmun=150060\&idtema=3\&search=pa ra|altamira|censo-agropecuario-2006. Acesso em 19 abr. 2015.

Instituto de Pesquisa Econômica Aplicada. (2010). O Brasil em quatro décadas. Texto para discussão, 1500. Brasília: IPEA. 100p.

Izumi, B.Y.; Wright, D.W.; Hamm, M.W. (2010). Farm to school programs: exploring the role of regionally-based food distributors in alternative agrifood networks. Agriculture and Human Values, 27 (3): 335-350.

Levine, S. (2008). School Lunch Politics: the surprising history of Americas favorite welfare programe. New Jersey: Princeton University Press. 250 p.

Lopes, D.E.; Almeida, R.A. (2012). Avaliação do Programa de Aquisição de Alimentos (PAA) e do Programa Nacional de Alimentação Escolar (PNAE) nos municípios de Castilho e AndradinaSP. Revista Pegada, 13 (1): 132-148.

Maluf, R.S. (2006). Segurança alimentar e fome no Brasil - 10 anos da Cúpula Mundial de Alimentação. Rio de Janeiro: CERESAN/CPDA/UFRRJ. 67 p.

Maluf, R.S.; Zimmermann, S.A. (2005). Políticas municipais de erradicação da fome e promoção da agricultura familiar no Brasil. Rio de Janeiro: CERESAN/CPDA/UFRRJ. 26 p.

Melão, I.B. (2012). Produtos sustentáveis na alimentação escolar: o PNAE no Paraná. Caderno IPARDES, 2 (2): 87-105.

Mendonça, M.; Rocha, C. (2015). Implementing national food policies to promote local Family agriculture: Belo Horizonte's story. Development in pratice, 25 (2): 160-173.

Mota, D.M.; Schmitz, H.; Silva Junior, J.F.; Porro, N.M; Oliveira, T.C.V. (2014). As catadoras de mangaba no Programa de Aquisição de Alimentos - PAA: um estudo de caso em Sergipe. Revista de Economia e Sociologia Rural, 52 (3): 449-470.

Ozelame, D.; Troian, A.; Cavalheiro, A. (2007). Valorizando o autoconsumo: alimentação e independência. Revista Brasileira de Agroecologia, 2 (1): 1264-1267.

Peixinho, A.; Balaban, D.; Rimkus, L.; Schwartzman, F.; Galante, A.P. (2011). Alimentação escolar no Brasil e nos Estados Unidos. O mundo da saúde 35 (2): 128-136. 
Institutional Markets for Family Agriculture: Analysis of the Food Acquisition Program (PAA) and the National School Feeding Program (PNAE) Within a Territory in the Brazilian Amazon ${ }^{1}$

Riches, G. (2002). Food Banks and Food Securrity: Welfare Reform, Human Rights and Social Policy. Lessons from Canadá? Social Policy \& Administration, 36 (6): 648-663.

Rocha, C. (2009). Developments in national policies for food and nutrition security in Brazil. Development Policy Review, 27 (1): 51-66.

Secretaria de Avaliação e Gestão da Informação. (2015). PAA DATA: Jan a Dez de 2014. Brasília: Secretaria de Avaliação e Gestão da Informação / Ministério do Desenvolvimento Social e Combate à Fome, [2015]. Disponível em:http: //aplicacoes.mds.gov.br/sagi/paa/2014/ resumo_new/pg_principal.php?url=geral_bra. Acesso em 16 abr 2015.

Santos, F.; Fernandes, P.F.; Rockett, F.C.; Oliveira, A.B.A. (2014). Avaliação da inserção de alimentos orgânicos provenientes da agricultura familiar na alimentação escolar, em municípios dos Territórios Rurais do Rio Grande do Sul, Brasil. Ciência e Saúde Coletiva, 19 (5): 14291436.

Saraiva, E.B.; Silva, A.P.F.; Sousa, A.A.; Cerqueira, G.F.; Chagas, C.M.S.; Toral, N. (2013). Panorama da compra de alimentos da agricultura familiar para o Programa Nacional de Alimentação Escolar. Ciência e Saúde Coletiva, 18 (4): 927-936.

Silva, A.K.; Egito, M. (2005). Rede de comercialização solidária de agricultores familiares e extrativistas do Cerrado: um novo protagonismo social. Agriculturas, 2 (2): 14-16.

Silva, T.C.R.; Gava, R.; Cirino, J.F.; Silva, E.A. (2012). Entre o potencial de transformação local e os entraves do Programa de Aquisição de Alimentos na cidade de Viçosa-MG. Administração Pública e Gestão Social, 4 (4): 399-419.

Simão, G.L.; Silva, E.A.; Silveira, S.F.R. (2014). Grau de cobertura do Programa de Aquisição de Alimentos (PAA) junto aos agricultores familiares do Estado de Minas Gerais. Revista de Economia e Sociologia Rural, 52 (3): 533-548.

Souza-Esquerdo, V.F.S.; Bergamasco, S.M.P.R. (2014). Análise sobre o acesso aos Programas de Políticas Públicas da Agricultura Familiar nos Municípios do Circuito das Frutas (SP). Revista de Economia e Sociologia Rural, 52 (1): 205-222.

Stolarski, M.C.; Castro, D. (2007). Caminhos da alimentação escolar no Brasil: análise de uma política pública no período de 2003-2004. Revista Paranaense de Desenvolvimento 1 (113): 3158.

Torres, F.L.; Torres, A.C.M.; Sobrinho, F.B.; Dias, T.F. Nunes, E.M. (2011). Inserção da agricultura familiar sustentável no PNAE: o caso da COOPAPI, Apodi-RN. Cadernos de Agroecologia 6 (2): 1-6.

Triches, R.M.; Schneider, S. (2010). Alimentação escolar e agricultura familiar: reconectando o consumo à produção. Saúde e sociedade, 19 (4): 933-945.

Turpin, M.E. (2009). A alimentação escolar como fator de desenvolvimento local por meio do apoio aos agricultores familiares. Segurança Alimentar e Nutricional 16 (2): 20-42.

Valnier, A.; Ricci, F. (2013). Programa de Aquisição de Alimentos (PAA): uma análise comparativa nos estados de Rondônia e Acre. Campo-Território: revista de geografia agrária 8 (16): 1982282013. 


\section{AUTHORS' BIOGRAPHY}
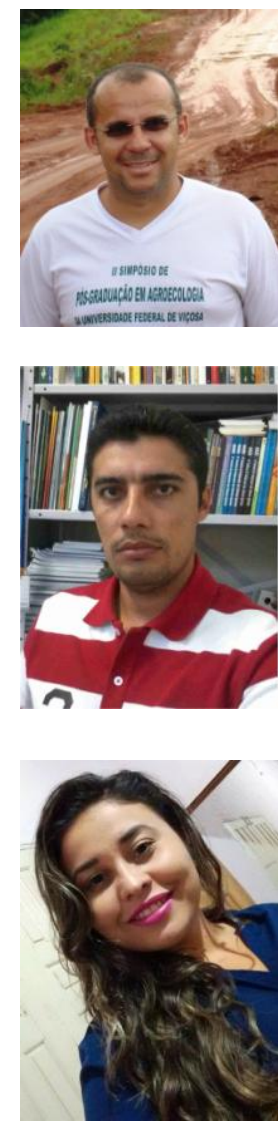

Galdino Xavier de Paula Filho, Agricultural technician from the Federal Agro technical School of Castanhal (2000), Agronomist by Federal University of Pará (2008), Master in Agro ecology by Federal University of Viçosa (2014), PhD (in progress) in Fitotecnia- Agro ecology by Federal University of Viçosa. Assistant professor A of by Federal University of Amapá, acting on the following topics: agro ecology, family farming, rural development, food security, traditional populations, medicinal plants and unconventional food plants (UCFP);

Miqueias Freitas Calvi, Graduated in Full Degree in Agricultural Sciences by Federal University of Pará (2004) and in Full Degree in Natural Sciences by Pará University State (2004).Master in Family Farming and Sustainable Development by Center for Agricultural Sciences and Rural Development of Federal University of Pará (2009). PhD (in progress) in Environment and Society by Campinas State University. Currently is professor in Federal University of Pará, Campus of Altamira and Coordinator of Extension Center in Territorial Development. Acting in the areas: Family farming, Public policy, Rural development, Rural extension, Agro ecology and Agrossilvi cultura is systems.

Roberta Rowsy Amorim de Castro, Studied Masters in Family Farming and Sustainable Development by Federal University of Pará (2013) in Postgraduate program in Amazon Agriculture and Graduate in Agronomy by Federal University of Pará/Campus of Altamira (2011). It has experience in the following areas: Family Farming, Systemic Approach, Family Production Systems, Communities and Traditional Populations in Amazon, Knowledge and Traditional Expertise and Public Policy of Territorial Development. 